\title{
The Mis-education of the African Child: The Evolution of British Colonial Education Policy in Southern Nigeria, 1900-1925
}

\author{
By Bekeh Utietiang Ukelina*
}

\begin{abstract}
Education did not occupy a primal place in the European colonial project in Africa. The ideology of "civilizing mission", which provided the moral and legal basis for colonial expansion, did little to provide African children with the kind of education that their counterparts in Europe received. Throughout Africa, south of the Sahara, colonial governments made little or no investments in the education of African children. In an attempt to run empire on a shoestring budget, the colonial state in Nigeria provided paltry sums of grants to the missionary groups that operated in the colony and protectorate. This paper explores the evolution of the colonial education system in the Southern provinces of Nigeria, beginning from the year of Britain's official colonization of Nigeria to 1925 when Britain released an official policy on education in tropical Africa. This paper argues that the colonial state used the school system as a means to exert power over the people. Power was exercised through an education system that limited the political, technological, and economic advancement of the colonial people. The state adopted a curricular that emphasized character formation and vocational training and neglected teaching the students, critical thinking and advanced sciences. The purpose of education was to make loyal and submissive subjects of the state who would serve as a cog in the wheels of the exploitative colonial machine.
\end{abstract}

\section{Introduction}

In his memoir, My Odyssey, the anticolonial nationalist, and Nigeria's first President, Nnamdi Azikiwe, tells the story of his days as a student at Hope Waddell Institute, Calabar. There, he learned from a fellow student about a great Negro liberator who was planning the liberation of Africa. As a son of a civil servant who worked for the colonial state, Azikiwe had no knowledge or awareness that Africa needed liberation. He boisterously told this student that their education was to prepare them to take over the positions of their parents. Realizing his ignorance, one of the students told him he was indeed a "hopeless, worthless idiot," words students used to refer to their school, "Hope Waddell Institute." Angry that the friend used these words to refer to him, he complained to his father when he returned home. His father informed him that some Africans were indeed "hopeless, worthless idiots," and that is why "they tolerated alien rule without organised resistance." ${ }^{1}$ This was a pivotal moment of awakening in

\footnotetext{
"Associate Professor, State University of New York Cortland, USA.

1. Nnamdi Azikiwe, My Odyssey: An Autobiography (New York: Praeger, 1970), 33.
} 
the life of the young Azikiwe. He wanted to know who this Negro liberator was and how he could redeem himself? His friend gave him an old mutilated copy of The Negro World, a newspaper that was published by Marcus Garvey. In it Garvey wrote, "God almighty created each and every one of us for a place in the world; and for the least of us to think that we were created only to be what we are, and not what we can make ourselves, is to impute an improper motive to the creator for creating us." ${ }^{2}$ Azikiwe found these words inspiring, and he was determined to learn more about Garvey. He shared his findings with his dad, who promptly told him that Garvey's writings were considered seditious by the colonial authorities and that he should be careful not to be caught with any of Garvey's literature. The encounter with Garvey and the Negro World changed his perspective, and he became a "social rebel." After graduating high school and taking a job as a civil servant, Azikiwe understood his economic insecurity in a colonial system that was exploitative of the labor of the colonized. He saw the unequal distribution of wealth, with most of it concentrated in the hands of the white supremacists ruling class who controlled mining, banking, and shipping. He also recognized that the colonial school system trained him to be subservient to the European class. Reflecting on this time in his life, he writes: "The first step towards my escape from being a perennial wage-earner was to become mentally equipped. I thought that I was not sufficiently educated to know how to seek for food, shelter, clothing and other amenities of life without slaving and vegetating. I planned to go to the United States and be re-educated from my mis-education."3

Azikiwe and other Nigerian students who went to school prior to 1925 were primarily educated in Christian Mission schools because western education was primarily the preserve of the missionaries and the colonial authorities made little investments by way of grants-in-aid to education. Britain's reluctance to invest in education in the colonies was rooted in the metropolitan practice of leaving education in the hands of the different Christian confessions, and it was also a way of running empire on a shoestring budget. The failure of Mission education to provide Azikiwe and his peers the intellectual skills they needed to reach their highest potentials led them to conclude that the school system has miseducated them. British colonial officials were also concerned about the quality and purpose of education that the missionaries were providing to African children and they took steps to formulate policies that would guide education in the colonies. This paper looks at the evolution of education policy in British colonial Africa, using Southern Nigerian provinces as a case study. In designing an education policy for Africa, colonial officials who were members of the Advisory Committee on Native Education in Tropical Africa drew lessons from India, where secular education became the culprit for the nationalist uprisings and unrests. This chapter historicizes the processes leading to the 1925 White Paper that laid out

2. Ibid, 34 .

3. Ibid, 45 . 
education policy in British tropical Africa. The essay argues that the greater involvement and intervention of the Nigerian colonial authorities in education resulted from the failure of the Mission schools to train personnel that will be a $\operatorname{cog}$ in the wheels of the colonial exploitative machinery; and the desire of the colonial government to train subjects that would be subservient, or what they called "good citizens."

\section{Christian Missionaries and Education}

Christian missionaries came to Nigeria in the sixteenth century. However, they never introduced a school system until around 1842 when Rev. Thomas Freeman and some Wesleyan Methodists arrived to begin a mission and a school. ${ }^{4}$ The first missionary school was established in 1843 by William de Graft and his wife in Badagry as the Methodist mission school. ${ }^{5}$ In the same year, King Eyo Nsa II of Creek Town in Efikland invited the British to begin a school. He said to them, "I can't sell slaves and don't know what for do for them. If I can get some cotton and coffee to grow, and men for teach me ... I be very glad. Mr Blyth tell me England glad for send me to teach book and make we understand God all same white man do."6 His request granted, Scottish Presbyterian missionaries from Jamaica established their mission in Calabar. Later, these missionaries established the Hope Waddell Institute, Calabar which Azikiwe and a host of many famous Nigerians such as Kingsley Mbadiwe, and Akanu Ibiam attended. The period between the mid-19 $19^{\text {th }}$ century and the official colonization of Nigeria in 1900 was a time of intensive missionization. Different European missionary groups were proselytizing their religious beliefs, and the practical means of achieving their objective was through Christian education. Education was inseparable from religious faith, and it became almost synonymous with missionization. With little or no input from the students, pupils enrolled in the school received baptism from ministers of whichever Christian denomination established the school they attended.

Concerns about the quality of education that was offered in the Christian mission schools emerged in the late 1890s and early 1900s. In 1892, Henry

4. Uche Uwaezuoke Okonkwo and Mary-Noelle Ethel Ezeh, "Implications of Missionary Education for Women in Nigeria: A Historical Analysis," Journal of International Women Studies 10, no. 2 (2008): 186.

5. Babs Fafunwa, History of Education in Nigeria (Ibadan: NPS Educational Publishers Limited, 1974), 82.

6. William H. Taylor, Mission to Educate: A History of the Educational Work of the Scottish Presbyterian Mission in East Nigeria, 1846-1960 (New York: E. J. Brill, 1996), 52. 
Rawlinson Carr was named the Inspector of Schools for the Colony of Lagos. ${ }^{7}$ Carr is a significant figure because he was the highest-ranking African in the colonial education service in Nigeria. As a distinguished scholar and an astute official, he rose through the colonial ranks and retired in 1924 as a Resident of the Colony. ${ }^{8}$ In 1899, Sir William McGregor, the Governor of the Lagos Colony, asked Carr to inspect schools in Calabar and Bonny. At this time, southern Nigeria (which was then a part of the Niger Coast Protectorate) was in transition from the administration of the Foreign Office to the Colonial Office, and Sir Richard Moor was the High Commissioner. After his inspection of the schools, Carr concluded that the results of the missionary efforts were small. The reason, he notes, is that "the missionaries look upon schools as the instruments for making converts, other men view as instruments for making good and useful citizens."9 Providing education was not the primary goal of the missionaries but a secondary goal. Education was incidental as it served the sole purpose of being the vehicle for conversions. As Babs Fafunwa has rightly noted, "if Christianity could have been implanted in Nigeria without the use of the school, most missionary groups would have tried to do so."10

The poor quality of education provided by the Christian missions necessitated the colonial government to begin taking steps toward regulating the sector. The education provided by the missionary groups served the purpose of helping the converts read the bible and sing Christian hymns. ${ }^{11}$ An attestation to this is the curriculum, which was heavy on religion and light on other aspects such as mathematics and the sciences. For example, at Hope Waddell Institute, Calabar, the daily schedule looked like this:

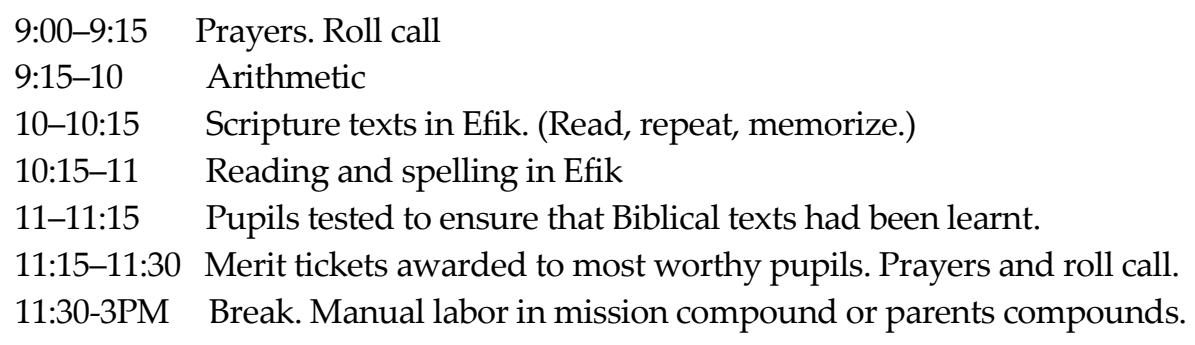

7. Prior to 1906, Nigeria was governed as three separate entities; the Crown Colony of Lagos, the Northern and Southern Protectorates. Lagos and the Southern Protectorate were amalgamated in 1906 and were now governed as the Southern Protectorate. The Northern and Southern Protectorates were amalgamated in 1914 creating for the first time the colony known as Nigeria.

8. Adewumi Fajana, "Henry Carr - Portrait of a Public Servant," Ilorin Journal of Education (1984).

9. Annual Report, Southern Nigeria 1899-1900 (HMSO: 1901), 12.

10. Fafunwa, History of Education in Nigeria, 1974, 91.

11. Folasade R. Sulaiman, "Internationalization in Education: The British Colonial Policies on Education in Nigeria, 1882-1926," Journal of Sociological Research 3, no. 2 (2012): 85. 
3-3:15PM Prayers. Roll call.

3:15-4PM Writing. Geography twice a week for standard 7.

4-5PM Reading and Scripture in English. The bible being the most common textbook.

5-5:15PM Merit tickets awarded. Calabar catechism recited. Hymn / prayer. 5:15-5:30PM Roll call \& Dismissal. ${ }^{12}$

Education focused primarily on religious conversion because the missionaries saw their work as saving Africa's "benighted savages."13 The focus of education was catechetical formation and this deprived the students of learning critical thinking and scientific skills prized in developing the society and bringing it to the industrial age that Europe was experiencing. For example, students educated in elementary schools operated by the churches were intellectually unprepared to attend a proposed high school and they were also unqualified to serve as clerks to the colonial governor. The impoverished nature of this education elicited a media outcry from newspapers such as the Anglo-African. ${ }^{14}$ The public pressure faced by the colonial state forced it to begin taking steps toward addressing the weaknesses of the school system. Thus, in 1877 the colonial government provided its first grant-in-aid of $£ 200$ to each of the three major missionary groups that were operating in Lagos. ${ }^{15}$ In-spite of the colonial state's interest in intervening in education, nevertheless it remained low in its priorities. For example, in the 1880 budget of the colony of Lagos which was $£ 45,000$, the colonial administration allocated $£ 700$ for education and $£ 16,000$ for prisons. ${ }^{16}$ These numbers reveal the priorities of the colonial state. The budget shows that the imprisonment of colonial bodies took precedence over their intellectual formation and this reveals one of the contradictions of colonial rule. It undoubtedly needed educated citizens for the state's prosperity, yet it was reluctant to invest in the education of the people. The colonial state abdicating its responsibility to the missionary groups was an attempt to run an empire on the cheap. If the missionaries were going to pay for the work of educating the colonial people through missionizing approaches, why intervene? Though both the missionary groups and the colonial state shared a broad goal of "civilizing the natives," their practical interests

12. Taylor, Mission to Educate: A History of the Educational Work of the Scottish Presbyterian Mission in East Nigeria, 1846-1960, 1996, 82.

13. Stephen J. Ball, "Imperialism, Social Control and the Colonial Curriculum in Africa," Journalism of Curriculum Studies 15, no. 3 (1983): 238.

14. Uyilawa Usanlele, "Development and Education in British Colonial Nigeria, 1940-55," in Developing Africa: Concepts and Practices in Twentieth-Century Colonialism (Manchester: Manchester University Press, 2014), 252-253.

15. Immaculata Nnenna Enwo-Irem, "Colonialism and Education: The Challenges for Sustainable Development in Nigeria," Mediterranean Journal of Social Sciences 4, no. 5 (2013): 164.

16. Usanlele, "Development and Education in British Colonial Nigeria, 1940-55," (2014), 252. 
differed, and this had an impact on the education offered. For the missionaries, the conversion of souls was their primary interest, and they needed the number of converts to show their benefactors back in Europe of how they were saving the souls of "pagan babies." For the colonial state, they needed human power in both the technical and secretarial services for the smooth running of the colonial machine. The inability of the missionaries to satisfy the immediate interests of the colonial state meant that the state must be more actively engaged in what happened in the education sector.

There was no clear consensus in the British colonial bureaucracy on the best approaches to intervention. The question was whether the colonial state should support secular education over mission education. Colonial officials, such as Frederick Lugard, were wary of secular education that did not have a specific goal of educating the pupils for good citizenship. The belief was that a secular education more concerned with intellectual abilities, rather than "integrity and good citizenship" was a failure. ${ }^{17}$ Reflecting on the Indian experiences of western education, the journalist, Valentine Chirol wrote in the early 1900s that while education is vital for the intellectual emancipation of the Indian, if this powerful medicine is not administered correctly, it could lead to other disorders. This is because education "acts upon the frame of an antique society as a powerful dissolvent, heating weak brains, stimulating rash ambitions, raising inordinate expectations of which the disappointment is bitterly resented."18 Chirol blamed education for the political and social unrests India was experiencing at the time. He notes that secular education was granted to a people who lived within primitive cultures and in an autocratic system, and western ideas of equality and freedom of speech were taught to them in the school system and now those Indians were using these ideas against the British. ${ }^{19}$ Avoiding the supposed "mistakes" of Indian education became of paramount interest to colonial officials as they attempted to craft an educational policy for Britain's territories in Africa.

Nigeria, Britain's most populous African colony was at the forefront of the development of education policy and one of the key architects of the 1925 White Paper, Frederic Lugard was the High Commissioner of Northern Nigeria from 1900 to 1906 and then the Governor of Nigeria from 1912 to $1919 .{ }^{20}$ Lugard's experiences in Nigeria shaped the education policies that he advocated in the 1920s. Before delving into the White Paper, it is crucial to first lay out the

17. Frederick Lugard, Education in Tropical Africa.The National Archives (Hereafter, TNA): CO 879/123/2, 3-4.

18. Victor Chirol, Indian Unrest (London: Macmillan, 1910), 7.

19. Ibid.

20. Before the Northern Protectorate and the Southern Protectorate of Nigeria were amalgamated in 1914 by Lugard, he was the Governor of both Protectorates from 1912 to 1914. 
evolution of mission education policies and practices in the southern provinces of Nigeria. ${ }^{21}$

\section{Mission Education in the Southern Provinces Nigeria}

In the southern provinces of Nigeria, many of the schools were operated by missionary groups. In 1882, the colonial administration introduced the first education ordinance because they wanted schools to educate pupils that would respond to the needs of the colonial state. This ordinance established a board of education, government approval for the opening of new schools, an annual examination of pupils in schools, the training and qualification of teachers, and provisions for grants-in-aid awarded to schools. ${ }^{22}$ Be that as it may, the proprietors of the missionary schools resisted some of these modest reforms because they were wedded to the religious orientations of their curricula. Tey did not see government efforts as ways of improving the quality of education provided but as attempts to change the religious orientation of their institutions. ${ }^{23}$ Nevertheless, the colonial government continued to support missionary schools and allowed them a free range in establishing new institutions. In the early 1900s, education in the Southern provinces of Nigeria (the Southern Protectorate and the Lagos colony) remained primarily the affair of the missionary organizations that operated in the region. The role of the government in education was limited to providing grants-in-aid and supervision of the schools. The missionary societies operating in the provinces were the Church Missionary Society, the Wesleyan Missionary Society, and the Roman Catholic missions. These schools provided elementary education, and the focus was on teaching the children to read the Bible in the vernacular. ${ }^{24}$ The government realized its efforts at improving the scope of education by providing Mission schools limited grants-in-aid that met some basic standards set by the government. In 1902, for example, the government provided $£ 1238$ in grants to some of these schools. ${ }^{25}$ The colonial government itself did not own or operate any schools in the protectorate.

21. This paper focuses on the Southern provinces of Nigeria. Education in the Northern provinces developed along different paths because of the presence of Arabic schools and the policy of Indirect Rule which was focused on maintaining the existing religious and political structures in Northern Nigeria. The implication of this policy is that Christian missionaries did not open as many schools in the Northern provinces as they did in the southern provinces.

22. Fafunwa, History of Education in Nigeria, 1974, 94.

23. Usanlele, "Development and Education in British Colonial Nigeria, 1940-55," (2014), 253.

24. Annual Report, Southern Nigeria 1902 (HMSO: 1903), 27.

25. Ibid, 28. 
Nevertheless, the colonial administration partnered with Hope Waddell Institute, Calabar.

Hope Waddell Institute was founded in 1894 by the United Free Church Mission. Hope M. Waddell was a missionary with the Scottish Missionary Society who arrived Calabar in 1846 to carry out evangelization work. The focus of this school was industrial, or vocational training as students acquired skills in printing, tailoring, and carpentry. In the early 1900s, students at Hope Waddell were primarily boarding students and they received some form of secondary education. Though a mission school, the colonial government provided the school grants and had some government students enrolled there. ${ }^{26}$ Without a government secondary school in the Southern Protectorate, the colonial administration took steps to expand the relationship with Hope Waddell Institute by not only enrolling government students at the school but also establishing a high school within the campus under the administration of the institute. The purpose of the High School was to provide industrial education and also general education of a higher level beyond what was currently offered at the institute or by any other school in the provinces. According to the plan, the High School will have both day and boarding students. All students were required to attend daily prayers but students could be exempted from religious instructions if their parents or guardians objected. ${ }^{27}$ These were attempts by the colonial administration to maintain a balance between secular education and religious education, accommodating non-Christian children in a school run by Presbyterian missionaries. This approach was more pragmatic than that taken in some provinces of Northern Nigeria. There, Frederick Lugard insulated a large part of the region from Western education for fear that its profoundly Christian influence will undermine the Islamic faith, thus eroding the religio-political structures upon which the colonial state in Northern Nigeria depended on for effective administration.

The cost of establishing a High School at Hope Waddell was $£ 15,000$ and over a third of this money was expended on new buildings that would house the school. ${ }^{28}$ Given the current state of the schools in the provinces, the colonial administration wanted to attract good students to fill the rolls of this school. A new education code, the Education Proclamation No. 19, came into effect on June 1, 1903. ${ }^{29}$ The goal of the new education policy was to ensure that proper education was provided at the primary and intermediate schools to better prepare the pupils for the High school. One of the incentives of this new policy was that the allocation of grants-in-aid should take into consideration students'

\author{
26. Ibid, 28. \\ 27. Ibid, 28. \\ 28. Ibid, 28. \\ 29. Annual Report, Southern Nigeria 1903 (HMSO: 1904), 25.
}


school attendance and performance at annual examinations. ${ }^{30}$ The new Code also empowered the Board of Education to draw up a syllabus of instruction for primary schools and to set the standards of exam for both the intermediate and high schools. ${ }^{31}$ In order to expand education in the territory, the code called for an extension of the system of district primary schools, and they were expectations they would evolve into government schools in the future. To support these schools, their funding came from three sources: government grants, trading firms and local chiefs, and tuition charged to the students. A district in need of a school was required to contribute an amount that was equal to the government grant and also provide a site for the school. If the school in question was a primary school, the locals were required to also pay for the building of the school and provide living quarters for the teacher. ${ }^{32}$ Within this district school system, education was a partnership between the colonial administration, the native administration, the trading companies, and the local people. Such cooperation is reflected in the local school committees that exercised some administrative role over the schools. By 1904, the Education Code was amended to vest control of schools on the High Commissioner instead of the Board of Education. With this change, the local boards lost control over school expenditures, though it still has a role overseeing the administration of the schools. The revenues generated by the schools were now going into the public purse and the schools were supported directly from the public purse. ${ }^{33}$

During this decade of the 1900s, education in the Southern provinces remained primarily in the domain of the missionary groups, while the colonial administration assisted the schools. The poor quality of education that was provided by the Christian missions necessitated the colonial government to begin taking steps toward supervision and intervention in the education sector. There was a realization that the mission groups were not able to meet the needs of the colonial state, and the colonial administration was no longer satisfied with limiting its intervention to grants but wanted to operate the schools. As the process of the colonial state's intervention in education unfolded, there were concerns among missionary groups that the colonial administration was encroaching into their domain. For example, the state started this process by providing grants to some of the mission schools, and then it began requiring standardize exams and class attendance. Over time, attendance and exam performance became yardsticks for assisting schools. Then assisted schools were subjected to the supervision of the government, and the government began insisting on the curricula for assisted schools. By 1908, the colonial government designed a new code to move the Nigerian school system from the English

30. Annual Report, Southern Nigeria 1902 (HMSO: 1903), 28.

31. Annual Report, Southern Nigeria 1903 (HMSO: 1904), 26.

32. Ibid, 26.

33. Annual Report, Southern Nigeria 1905 (HMSO: 1906), 29. 
Education code because it believed that the code was not suitable for West Africa. The goal of this new code was to do two things, the provision of both a "liberal literacy education" and a "useful and practical education." 34 The code mandated the 3Rs (reading, writing, and arithmetic) to be taught in vernacular to children from infant to Standard II. At the primary school level (which began from infant to Standard VII), the 3Rs were to be taught in the English language in addition to other subjects such as drawing, shorthand, hygiene, manual training, and the science of common things. At the secondary level, students took classes in geometry, natural science, history, geography, language (one language besides English) in addition to the subjects that they took in Standards V to VII. ${ }^{35}$

The secondary school was the highest form of education received by the students in the provinces. In terms of the curricula and education offered, these secondary schools were not comparable to those in Britain. In practical terms, these were higher grades of "elementary schools containing classes in which instruction is given in the subjects of the higher Standards of the Education Code, together with a somewhat enlarged curriculum of literary or technical subjects." 36 Tuition fees at the secondary schools were higher, and the teachers were better qualified than those at the elementary schools. Also, students at the secondary schools took extra subjects such as Latin, Greek, French, elementary algebra and geometry, book-keeping, shorthand, and typewriting. ${ }^{37}$ The last three skills were in high demand by the colonial administration and also by the different trading firms that operated in the colony. Parents or communities were willing to pay higher tuitions for their wards in the secondary schools because these were pathways to more "professional" jobs in the colonial service or industry. Before 1909, only two government secondary schools existed in the southern provinces, and these were the Hope Waddell Institute in Calabar and the Ogugumanga Industrial Institute, Bonny.

The turning point for secondary education in Nigeria was the 1909 government's establishment of King's College in Lagos to set a higher standard of secondary education in the colony. ${ }^{38}$ It is not coincidental that it was only after the establishment of this school that the Cambridge Local Examinations took place for the first time in the colony. Of the six students from King's College that entered the junior examination in 1909, three of the boys were successful. ${ }^{39}$

34. Annual Report, Southern Nigeria 1908 (HMSO: 1909), 23.

35. Ibid, 23.

36. Annual Report, Southern Nigeria 1907 (HMSO: 1908), 17.

37. Ibid, 17.

38. Annual Report, Southern Nigeria 1908 (HMSO: 1909), 25.

39. Annual Report, Southern Nigeria 1910 (HMSO: 1911), 23. 


\section{The Future of Education in Africa}

King's college was an important step by the colonial government to expand its footprints in the education sector. By the end of 1911, the government was operating about sixty schools and with a total enrollment of 5,399 boys and 238 girls and total expenditures of $£ 27,159.40$ The competition between the different Protestant Missions in Africa and the expanding government role in the education sector necessitated the missionary groups to rethink their strategies in Africa. At the 1910 World Missionary Conference (also the Edinburgh Missionary Conference) that Protestant and Anglican groups gathered to consider challenges in the missionization of the Non-Christian world, a consensus emerged that missionaries in Africa should coordinate their efforts in areas of education and medicine. After the conference, a select committee on education headed by A. H. L. Fraser was established. ${ }^{41}$ This committee proposed a memorandum addressing the future of education in West Africa to the Colonial Office in April of 1914. The memorandum "asked for a general policy on education in the African colonies, general policy outlining the role of the colonial Governments and the establishment of a commission to examine the policy." 42 The Colonial Office rejected the suggestion of a commission on the basis that the colonies knew what their educational needs were. Nevertheless, they asked the committee to propose a policy on education. ${ }^{43}$ People at the International Missionary Council understood that many at the Colonial Office were sympathetic to their cause, and a cooperative arrangement with colonial governments was, in the long run, beneficial to their missionization work. Such arrangements will allow the government to exercise some supervisory role over the mission schools without necessarily becoming competitors. In sum, there were two reasons why the missions needed a policy on education in tropical Africa. The first was to align policy with the metropolitan approach of cooperation between church and state and invariably to avoid the American approach of separation between church and state. The second reason was to ensure that African education was not merely scholastic but adapted to the interests and needs of the African people. ${ }^{44}$ Work on coming up with a policy took a hiatus between 1914 and early 1920 because of the First World War which interrupted activities both in the metropole and colony as efforts were directed toward the war.

40. Annual Report, Southern Nigeria 1911 (HMSO: 1912), 20.

41. Clive Whitehead, "Education Policy in Tropical Africa: The 1925 White Paper in Retrospect," History of Education 10, no. 3 (1981): 195.

42. Matthew B. Gwanfogbe, Changing Regimes and Educational Development in Cameroon (Spears Media Press, 2018), 84.

43. Ibid, 84 .

44. James F. Clatworthy, The Formulation of British Colonial Education Policy, 19291961. Report for Office of Education (DHEW) (Washington, DC: Office of Education (DHEW), 1969), 9. 


\section{The Phelps-Stokes Commission Report}

Following World War I, there was renewed interest on education in Africa, most especially from the American missionary groups. One group interested in Africa was the American Baptist Foreign Missionary Society. In order to expand its education mission on the continent, the missionary group saw it necessary to study the state of education in Africa. The Phelps-Stokes Fund was approached to provide support for this study. ${ }^{45}$ Before this time, the Fund had not done any work on education in Africa. However, it was the intention of the founder of the Fund that the money should be used "for educational purposes in the education of Negroes both in Africa and the United States."46 The Phelps-Stokes Commission visited Africa between 1920 and 1923 to examine the state of African education and Nigeria was one of the colonies visited. A key proposal in the Commission's first report was the adaptation of African education. The report argued that the failure to adapt to Native education is partly responsible for the failure of education in Africa. ${ }^{47}$ The report notes that like in India, African schools prepared clerks for the state and reproduced teachers to the neglect of "activities that are more fundamental in the economic and social development of their country." 48 The report also highlights the complaints of African chiefs that their educated children have become estranged from their culture. ${ }^{49}$ In proposing a policy of adaptation of African education, the Commission adopted a policy that has an agrarian bias, arguing that "the future of all organizations in Africa depends more upon the effective use of the soil than upon any other of the numerous resources in the continent." 50 By pushing agriculture as the path to development for African states, the Commission's report ideologically aligned itself with the colonial administrations that did not envisage an industrialized Africa but an Africa that was the producer of primary products for European industries.

Rather than providing African children with an education that was at par with their European counterparts, the Phelps-Stoke Commission proposed a policy of adaptation that undercut the progress of African people under the disguise of helping Africans develop along their native lines. It is for this reason that the Commission strongly recommended the teaching of such things as African crafts rather than the sciences that could have provided African children with the knowledge base to industrialize and produce higher scientific research.

45. Phelps-Stokes Commission, Education in Africa. Report of the Phelps-Stokes Commission (New York, 1922), XII.

46. Ibid, XII.

47. Ibid, 16 .

48. Ibid, 17.

49. Ibid, 17.

50. Ibid, 17. 
There was nothing uniquely African that prevented Africa from embracing the industrial age as the Europeans given that not many decades earlier, conditions in Europe were similar to those in Africa. While the Commission's report opened up by speaking positively about African people and their level of intelligence, in its recommendations, it quickly defaulted to the condescending attitudes EuroAmerican white supremacist powers have about Africans and treated Africans as helpless subjects in need of foreign tutelage. Although the National Congress of British West Africa had demanded an institution of higher learning in the early 1920s, the Phelps-Stokes Commission argued that it was premature to establish a full-fledged university in West Africa. The Commission recommended that the lone college in West Africa that offered university degrees in the humanities, the Fourah Bay College in Sierra Leone, should alter it programs toward technical education. ${ }^{51}$

In pushing for technical education for Africans, the Commission was aligning itself with the Tuskegee Style of education promoted by Booker T. Washington in the United States. Washington promoted this style of education at Tuskegee Institute, where he was founder and principal from 1881 to 1915 . He advocated vocational and industrial training for African Americans over liberal arts education. In his Atlanta Compromise Speech of 1895, he said, "Cast it down in agriculture, mechanics, in commerce, in domestic service, and in the professions. ...No race can prosper till it learns that there is as much dignity in tilling a field as in writing a poem. It is at the bottom of life we must begin, and not at the top." ${ }^{52}$ W. E. B. Dubois was critical of Washington and considered his ideas on industrial and vocational education misguided. Dubois argued that Washington's program at Tuskegee "practically accepts the alleged inferiority of the Negro races."53 The lone African member of the Commission, James K. Aggrey agreed with the proposal. Thomas Howard argues that Aggrey, like Washington, was an accommodationist and he embraced Book T. Washington's philosophy. ${ }^{54}$ Aggrey was not looking for radical transformations in the African education system but a "gradual evolutionary reform within the framework of the British Empire." 55 The ideas proposed by the Phelps-Stokes Commission were well received by missionary groups working in Africa and these made their way

51. Thomas Howard, "Black Missionary Influence on the Origins of University Education in West Africa," in Black Americans and the Missionary Movement in Africa, ed. Jacob Sylvia (Westport: Greenwood Press, 1982), 97.

52. Booker T. Washington, Atlanta Compromise. Retrieved from: https://www.loc.gov /exhibits/civil-rights-act/multimedia/booker-t-washington.html. [Accessed 10 March 2020.]

53. Robert J. Norrell, "Booker T. Washington: Understanding the Wizard of Tuskegee," Journal of Blacks in Higher Education, 42 (2003-2004), 96.

54. Howard, "Black Missionary Influence on the Origins of University Education in West Africa," 1982, 99.

55. Ibid, 99. 
into the 1925 White Paper that became Education Policy in British Tropical Africa. This was made possible because J. H. Oldham, the secretary of the International Missionary Council cooperated with the Phelps-Stokes Commission in its work. ${ }^{56}$

\section{The 1925 White Paper}

Following the Commission's visit to Africa, Oldham approached the Colonial Office requesting that there should be a policy on education in the colonies. The Colonial Office asked Oldham to prepare a memorandum on this initiative to be provided to the colonial governors in the impending conference of governors of African colonies. ${ }^{57}$ Oldham's memorandum was well received by the governors, who agreed that an advisory committee should be set up in London to look into cooperation between the Missions and the British colonial governments. ${ }^{58}$ The Advisory Committee that was put together comprised of people who were either affiliated with the Christian Missions or officials who were sympathetic or supportive of the missionary cause in the colonies. ${ }^{59}$ It was this committee that put together the 1925 White Paper. Frederick Lugard was the author of the White Paper's draft, as he took the initiative to draft it in collaboration with Oldham even before the assignment was given to him. ${ }^{60}$ Many of the ideas in the White Paper are similar to those in the Phelps-Stokes Commission report. Some examples include the adaptation of education, character formation, Christian moral education, the emphasis on African education.

This essay considers two key policy ideas contained in the White Paper: the idea of adapting the education of African children along "native lines" and the idea of education for character formation/good citizenship. The policy states:

Education should be adapted to the mentality, aptitudes, occupations and traditions of the various peoples, conserving as far as possible all sound and healthy elements in the fabric of their social life; adapting them where necessary to changed circumstances and progressive ideas, as an agent of natural growth and evolution. Its aim should be to render the individual more efficient in his or her condition of life, whatever it may be, and to promote the advancement of the community as a whole through the improvement of agriculture, the development of native industries, the

56. Phelps-Stokes Commission, Education in Africa, 1922, XXII.

57. Clive Whitehead, "Education Policy in Tropical Africa: The 1925 White Paper in Retrospect," (1981): 196.

58. Ibid, 197.

59. Ibid, 197.

60. Ibid, 197. 
improvement of health, the training of the people in the management of their own affairs, and the inculcation of true ideals of citizenship and service. ${ }^{61}$

While a cursory look at this policy might seem sensitive to the needs and conditions of the African child, in reality, it was a racist policy. Educated Africans at the time argued for European curriculum because they saw adaptation as a sign that Africans were intellectually deficient and unable to comprehend and absorb what their European counterparts were taught. ${ }^{62}$ The curriculum proposed for African children was not at par with what children in Europe were taught. Adapting education to the African culture and environment had the effect of keeping African children in their 'backward, tribal, agrarian' status. Frederick Lugard argued that adapting education would help combat any forms of agitation and this was good for the stability of the empire. In a nutshell, Lugard wanted Africans to be kept in "their place" by limiting literacy so that they would not be hostile to the colonial state. ${ }^{63}$

The expansion of colonial education was to be achieved through the village school. In his commentary on the White Paper, Lugard explained that the village school was going to be a mission school with a native teacher. He wrote, "The first object of the school should be to make the pupils more efficient in the every-day work of village life - in village arts and crafts and in agriculture and animal husbandry."64 The emphasis here is on vocational education such as learning crafts, hygiene, sanitation, and farming. The colonial school system was not intended to help Africans think critically but to enable them do things with their hands. When the children were introduced to literary content, emphasis was on roth memorizations over comprehension and this defeats the critical thinking purpose of education.

In his essay, The Purpose of Education, Martin Luther King, Jr. writes, "It seems to me that education has a two-fold function to perform in the life of man and in society: the one is utility and the other is culture. Education must enable a man to become more efficient, to achieve with increasing facility the legitimate goals of his life. Education must also train one for quick, resolute and effective thinking. To think incisively and to think for one's self is very difficult. We are prone to let our mental life become invaded by legions of half truths, prejudices, and propaganda. ...The function of education, therefore, is to teach one to think intensively and to think critically."65 Colonial education emphasized the

61. W. Ormsby-Gore, A.G. Church et al., Education Policy in British Tropical Africa. Cmd. 2374 (London: HMSO, 1925), 4.

62. D. N. Sifuna, British and French Colonial Education Policies and Educational Changes in Africa (Nairobi, Kenya: Kenyatta University College, 1977), 6.

63. Ibid, 2.

64. Lugard, "Education in Tropical Africa." The Edinburgh Review 493 (1925): 6.

65. Martin Luther King Jr., The Purpose of Education (Atlanta, Ga: Maroon Tiger, 1947), 10. 
functional aspects of education over the critical thinking aspects. Limiting the education of African children was not an accident but a racist policy to keep Africans submissive to the colonial machine. A colonial official in southern Africa wrote in 1902 that, "The black peril will become a reality when the results of our misguided system of education have taken root and when the veneer of European civilization struggles with the innate savage nature [of the African]."66 This official believed that substandard mission education was too generous to the colonial people. In a letter to the Rhodesia Herald, a white person wrote, "I do not consider it right that we should educate the native in any way that will unfit him for service. He is, and always should be a hewer of wood and drawer of water for his [white] master."67 There is no doubt that racial pseudo-scientific notions that blacks were not mentally capable of absorbing liberal arts education and the higher sciences were some of the reasons for denying African children a good education. ${ }^{68}$

A vocational education system was economically advantageous to the colonial state because a highly educated elite will refuse to be a cog in the exploitation machine of the colonial state. The crafts and agricultural products produced by the people were commodities of trade in Europe, where they generated revenues for the colonial state. Most colonial governments in West Africa did not rely on plantation agriculture for exports but subsistent agriculture. Teaching farming to the people and helping them to increase yields was an effective means of raising revenues for the provincial coffers. Thus, the emphasis on agricultural education and extension programs. Furthermore, by failing to educate the people to think critically and to think for themselves, it was a colonial suppressive strategy to prevent the colonized from challenging the shaky foundations upon which colonial rule rested. If colonial rule is a benevolent civilizing mission why the exploitation of the colonized? Colonized subjects trained in the art of critical thinking and exposed to the ideas of liberty and equality, the very foundations of western democracies will sooner or later begin to challenge the basis of colonialism because the system was based neither in the equality or liberty of the people but on exploitation and dehumanization.

The second policy idea is character education/good citizenship. The curriculum emphasized teaching the students the true ideals of citizenship. The intellectual and moral bankruptcy of this policy becomes even more glaring when Lugard's commentary is analyzed. Lugard wrote, "The fundamental principle of the education policy now advocated is that the training of character is more important than the training of the intellect - that the development of the quality of integrity, self-reliance, and a sense of responsibility as an individual and as a

66. Dickson A. Mungazi, The Underdevelopment of African Education: A Black Zimbabwean Perspective (Washington, DC: University Press of America, 1982), 16.

67. Ibid, 16.

68. Ibid, 6 . 
citizen, is of greater moment both to the individual to the state than high proficiency in the passing of examinations."69 The formation of character is an essential aspect of every education system. Babs Fafunwa identifies seven cardinal goals of traditional African education, and he says the objective of these was "to produce an individual who is honest, respectable, skilled, co-operative and conforms to the social order of the day."70 These goals are the development of physical skills, character, respect for elders, intellectual skills, acquisition of vocational training, development of a sense of belonging to the community, and the understanding and appreciation of cultural heritage. ${ }^{71}$ Traditional African education did not preclude the formation of character; neither did it make intellectual formation a secondary matter. It was the narrowness and the motive of the colonial regime's idea of "character" and "good citizenship" that is problematic. What did the colonial system mean by good citizenship? In liberal democracies, citizenship is often associated with rights and privileges guaranteed by the state and endowed with certain electoral franchises. The colonial state did not guarantee its subjects (citizens) these rights. As Emma Hunter has argued, the colonial state was envisioning a new political state in which citizenship was understood in relation to one's duties to the state. What the colonial state promised its subjects were neither the electoral franchises nor liberty and equality, rather security and some progress. ${ }^{72}$ The expectations were that good citizens would humbly submit themselves to the colonial state, which exercised both paternal and maternal roles over them and would also dutifully pay their varied forms of taxes to the state. The idea of Indirect Rule championed by zealous colonial officials such as Frederick Lugard aimed at depriving Africans of citizenship as understood in liberal democracies.

The question then is this, how is good citizenship taught to people denied the basic tenets of citizenship? The primary motif of education for good citizenship is social control. Education is an ideological state apparatus, a way state power is exercised. ${ }^{73}$ Schools were places of moral training, and religious ideologies such as respect for authority were vital tenets for this. ${ }^{74}$ For some in the colonial state, they were lessons to be learned from the Indian experience where they had spent substantial resources on an educational system that produced "bad citizens." They were termed "bad citizens" because they opposed Britain's exploitation and were agitating for more inclusive governance and rights, a civic

69. Ibid, 10

70. Fafunwa, History of Education in Nigeria, 1974, 20.

71. Ibid, 20 .

72. Emma Hunter, "Dutiful Subjects, Patriotic Citizens, and the Concept of 'Good Citizenship' in Twentieth-Century Tanzania," The Historical Journal 56, no. 1 (2013): 267.

73. Rugano Jones Zuobgu, Colonialism and Education in Zimbabwe (Harare: SAPES Books, 1994), 2.

74. Ibid, 2. 
duty in a democratic state. At the turn of the twentieth century, Septimus Smet Thorburn a long-serving British colonial official in the Punjab frontier district of India, castigated the colonial form of education as being responsible for the agitations by Indian nationalists. The offense of these "westernized Indians" is that they were demanding more places in the political leadership of their state. Thorburn writes, "That Westernized Indians, believing themselves fully equipped for place and power in the administration of their own country, should push their claims, has long been recognized as one of the inevitable consequences of our educational system in India,... That the teachings of some of the leaders in the movement should become seditious was, doubtless also foreseen, but that those teachings should excite anti-English disturbances has taken most of us by surprise."75 He went on to argue that the colonial system of education in India has failed because "the literate are few and discontented, the masses are still illiterate." 76 His solution to the problem was for the government of India to provide a comfortable residential club for Indian students in London and appoint for them an English gentleman who is "thoroughly sympathetic" as a managing secretary or their guardian. He said that Indian students who enjoyed the club's hospitality "would return to their motherland with feelings of gratitude to their Government, and with a decided bias towards good, not bad, citizenship."77 Absent in this argument is the colonial state providing the colonized fundamental rights and privileges of citizenship. Inherent in Thorburn's argument was the belief that Indian education, which focused mostly on the urban elites to the neglect of the rural dwellers did not do enough to train the people to be good citizens of the state. Education for citizenship thus will mean teaching colonial people to be pliant and submissive to the white supremacist overlords who reigned over them. Central to the mission of this form of education is social control.

The colonial school system was not interested in developing Africans to usher in their progress. The assumption of the colonizers was that in the foreseeable future, Africans will stay under the tutelage of their European masters. So, the Advisory Committee on Education advocated a policy of education that will educate Africans as messengers, clerks, tradespeople, and agricultural assistants. ${ }^{78}$ For example, In Nigeria, Yaba Higher College established in 1932 was to provide "training of a university or professional character, although as a great deal of attention will be devoted to the practical side ... the course will not be so wide, especially on the theoretical side, as would be

75. S. S. Thurburn, "Education and Good Citizenship in India," in Proceedings of the Royal Colonial Institute 39 (Royal Commonwealth Society, 1908), 134-135.

76. Ibid, 139.

77. Ibid, 142.

78. J.F.A. Ajayi, L.K.H. Goma and G.A. Johnson, The African Experience with Higher Education (London: James Currey, 1996), 44. 
necessary to obtain university or professional qualifications in the United Kingdom."79 Theoretically, students who went to Yaba College could obtain equivalent qualifications as European students; in practice, the system maintained the subordination of Africans to the Europeans. For instance, African medical assistants who graduated from Yaba College made $£ 120$, whereas their European counterparts working in Nigeria performing similar duties made $£ 400$. Ajayi et al. note that "Success in examinations was tied more to vacancies and character evaluation than to performance. Registration for overseas examinations was discouraged and courses essential for such examinations were often eliminated from the curricula, thus ensuring that the College Diploma remained strictly of local significance."80 By design, the colonial system of education was to limit the success of African children. By using character rather than performance in evaluating students, the colonial state wanted to exclude potential "troublemakers," i.e., those who may challenge the exploitative tendencies of the colonizer.

While colonial policy attempted to improve the standards of mission schools by putting in place education policies and also creating government schools, the two school systems were two sides of the same coin. Mission schools advanced the imperialistic objectives of the colonial state by tilling the soil that made it possible for colonial rule to thrive. Christian mission education achieved this aim by preparing "Africans spiritually and mentally for physical domination."81 Mission schools educated African children to abandon their religious rituals, reject their cultural history and traditions, and to perceive these as backward and superstitious, while wholeheartedly embracing European history and culture as superior. It was not uncommon for African children to look down on their own cultures while gracefully assuming the second-class status that the colonial state conferred upon them. As Magnus Bassey notes, participants at a conference on the Review of the Educational System of Eastern Nigeria in the 1950s were without a doubt in agreement that colonial mission education did not "adequately meet the needs of the country." 82 When Nnamdi Azikiwe confesses that as a young man, he was ignorant of Africa's need for liberation, it attests to the success of the missionization and colonizing nature of the British colonial school system in Africa. A person not aware of their imprisonment has no need to fight for freedom. The imperial school system did what it was supposed to do, miseducate African children.

79. Ibid, 46.

80. Ibid, 46 .

81. Magnus O. Bassey, Western Education and Political Domination in Africa: A Study in Critical and dialogical Pedagogy (Westport, Connecticut: Bergin \& Garvey, 1999), 40.

82. Ibid, 41 . 


\section{Conclusion}

Britain's colonial education policy in Nigeria evolved in the period between 1900 and 1925 and continued to evolve thereafter. In the early years, the colonial state failed to invest in the school system because it saw education as the preserve of the different Christian missionary groups that were in Nigeria. It was when the school system run by the Christian missions failed to respond to the needs of the colonial state that necessary interventions were made. These interventions included grants in aid, standardized curriculum, school supervisions, government schools, and policies on the purpose of education. The paper argues that Christian missions were more interested in converting Africans than providing the education that the colonial state wanted and that African children needed. For the colonial state, the purpose of education was to form good citizens who would serve the needs of the colonial state in clerical, vocational, and agricultural fields. The expanding role the government undertook during this period, elicited fears in the minds of the Christian mission groups leading them to find areas of cooperation with the Colonial government. It was this cooperative arrangement that led to the 1925 White Paper on education policy.

This essay has shown that the miseducation of African children happened in several ways: the colonial government underinvested both financial and human resources in education; missionary societies delivered a program of miseducation as their primary interest or emphasis was on the conversion of African children and making them reject their religious and cultural traditions. In conclusion, the African colonial school system was a system of deformation where African children were taught not to think critically but to be cogs in the wheels of the European White supremacist colonial exploitative economic system. This was not education but a program of mis-education.

\section{Bibliography}

Ajayi, J. F.A., L.K.H. Goma and G.A. Johnson. The African Experience with Higher Education. London: James Currey, 1996.

Azikiwe, Nnamdi. My Odyssey: An Autobiography. New York: Praeger, 1970.

Ball, Stephen J. "Imperialism, Social Control and the Colonial Curriculum in Africa." Journal of Curriculum Studies 15, no. 3 (1983): 237-263.

Bassey, Magnus O. Western Education and Political Domination in Africa: A Study in Critical and Dialogical Pedagogy. Westport, Connecticut: Bergin \& Garvey, 1999.

Chirol, Victor. Indian Unrest. London: Macmillan, 1910.

Clatworthy, James F. The Formulation of British Colonial Education Policy, 1929-1961. Report for Office of Education (DHEW). Washington, DC: Office of Education (DHEW), 1969. 
Colonial Reports: Annual No. 315: Southern Nigeria. Reports for 1899-1900. London: HM Stationery Office, 1901.

Colonial Reports: Annual No. 405: Southern Nigeria. Reports for 1902. London: HM Stationery Office, 1903.

Colonial Reports: Annual No. 433: Southern Nigeria. Reports for 1903. London: HM Stationery Office, 1904.

Colonial Reports: Annual No. 507: Southern Nigeria. Reports for 1905. London: HM Stationery Office, 1906.

Colonial Reports: Annual No. 680: Southern Nigeria. Reports for 1908. London: HM Stationery Office, 1909.

Colonial Reports: Annual No. 695: Southern Nigeria. Reports for 1910. London: HM Stationery Office, 1911.

Colonial Reports: Annual No. 735: Southern Nigeria. Reports for 1911. London: HM Stationery Office, 1912.

Enwo-Irem, Immaculata Nnenna. "Colonialism and Education: The Challenges for Sustainable Development in Nigeria." Mediterranean Journal of Social Sciences, 4, no. 5 (2013): 163-168.

Fafunwa, Babs. History of Education in Nigeria. Ibadan: NPS Educational Publishers Limited, 1974.

Fajana, Adewumi. "Henry Carr - Portrait of a Public Servant." Ilorin Journal of Education (1984).

Gwanfogbe, Matthew B. Changing Regimes and Educational Development in Cameroon. Spears Media Press, 2018.

Howard, Thomas. "Black Missionary Influence on the Origins of University Education in West Africa." In Black Americans and the Missionary Movement in Africa, edited by Jacob Sylvia. Westport: Greenwood Press, 1982.

Hunter, Emma. "Dutiful Subjects, Patriotic Citizens, and the Concept of 'Good Citizenship' in Twentieth-Century Tanzania." The Historical Journal 56, no. 1 (2013): 257-277.

King, Martin Luther Jr. The Purpose of Education. Atlanta, Ga: Maroon Tiger, 1947.

Lugard, Frederick. "Education in Tropical Africa." The Edinburgh Review 493 (1925): 1-19. . Education in Tropical Africa.The National Archives: CO 879/123/2.

Mungazi, Dickson A. The Underdevelopment of African Education: A Black Zimbabwean Perspective. Washington, DC: University Press of America, 1982.

Norrell, Robert J. "Booker T. Washington: Understanding the Wizard of Tuskegee." Journal of Blacks in Higher Education 42 (2003-2004): 96-109.

Okonkwo, Uche Uwaezuoke and Mary-Noelle Ethel Ezeh. "Implications of Missionary Education for Women in Nigeria: A Historical Analysis." Journal of International Women Studies, 10, no. 2 (2008): 186-197.

Ormsby-Gore, W., A.G. Church et al. Education Policy in British Tropical Africa (Cmd 2374). London: HMSO, 1925.

Phelps-Stokes Commission. Education in Africa. Report of the Phelps-Stokes Commission. New York, 1922.

Sifuna, D. N. British and French Colonial Education Policies and Educational Changes in Africa. Nairobi, Kenya: Kenyatta University College, 1977.

Sulaiman, Folasade R. "Internationalization in Education: The British Colonial Policies on Education in Nigeria, 1882-1926." Journal of Sociological Research 3, no. 2 (2012): 84-101. 
Taylor, William H. Mission to Educate: A History of the Educational Work of the Scottish Presbyterian Mission in East Nigeria, 1846-1960. New York: E. J. Brill, 1996.

Thurburn, S.S. "Education and Good Citizenship in India." In Proceedings of the Royal Colonial Institute 39. Royal Commonwealth Society, 1908.

Usanele, Uyilawa. "Development and Education in British Colonial Nigeria, 1940-55." In Developing Africa: Concepts and Practices in Twentieth-Century Colonialism. Manchester: Manchester University Press, 2014.

Washington, Booker T. Atlanta Compromise. Retrieved from: https:/www.loc.gov/exhibits/ civil-rights-act/multimedia/booker-t-washington.html. [Accessed 10 March 2020.] 